\title{
Effect of point mutations on Herbaspirillum seropedicae NifA activity
}

\author{
B. Aquino, A.A. Stefanello, M.A.S. Oliveira, F.O. Pedrosa, E.M. Souza, \\ R.A. Monteiro and L.S. Chubatsu
}

Departamento de Bioquímica e Biologia Molecular, Universidade Federal do Paraná, Curitiba, PR, Brasil

\begin{abstract}
NifA is the transcriptional activator of the nif genes in Proteobacteria. It is usually regulated by nitrogen and oxygen, allowing biological nitrogen fixation to occur under appropriate conditions. NifA proteins have a typical three-domain structure, including a regulatory $\mathrm{N}$-terminal GAF domain, which is involved in control by fixed nitrogen and not strictly required for activity, a catalytic $\mathrm{AAA}+$ central domain, which catalyzes open complex formation, and a C-terminal domain involved in DNA-binding. In Herbaspirillum seropedicae, a $\beta$-proteobacterium capable of colonizing Graminae of agricultural importance, NifA regulation by ammonium involves its N-terminal GAF domain and the signal transduction protein GInK. When the GAF domain is removed, the protein can still activate nif genes transcription; however, ammonium regulation is lost. In this work, we generated eight constructs resulting in point mutations in $H$. seropedicae NifA and analyzed their effect on nifH transcription in Escherichia coli and $H$. seropedicae. Mutations K22V, T160E, M161V, L172R, and A215D resulted in inactive proteins. Mutations Q216I and S220I produced partially active proteins with activity control similar to wild-type NifA. However, mutation G25E, located in the GAF domain, resulted in an active protein that did not require GInK for activity and was partially sensitive to ammonium. This suggested that G25E may affect the negative interaction between the N-terminal GAF domain and the catalytic central domain under high ammonium concentrations, thus rendering the protein constitutively active, or that G25E could lead to a conformational change comparable with that when GInK interacts with the GAF domain.
\end{abstract}

Key words: Biological nitrogen fixation; Herbaspirillum seropedicae; NifA

\section{Introduction}

Biological nitrogen fixation is a process carried out by some prokaryotes that reduces dinitrogen $\left(\mathrm{N}_{2}\right)$ to ammonia $\left(\mathrm{NH}_{3}\right)$ in a reaction catalyzed by the nitrogenase complex. It is highly energy-demanding and is thus controlled at both transcriptional and translational levels (1). Transcription of the nif genes, which encode the nitrogenase complex and all gene products necessary to assemble an active enzyme, is controlled by NifA in response to ammonium and oxygen levels. NifA is a $\sigma^{54}$-dependent transcriptional activator that shows a typical three-domain structure. The N-terminal GAF domain shows the lowest similarity among NifA homologs, and is involved in ammonium control. The central AAA+ domain interacts with the $\sigma^{54}$-RNA polymerase and possesses ATPase activity, while the C-terminal domain shows a helix-turn-helix motif involved in DNA-binding. Two linkers connect these domains: the Q-linker connects GAF and central domains, and the ID-linker connects the central and C-terminal domains.
NifA proteins are separated into two classes based on their regulation by ammonium and oxygen (1). One class occurs in $\gamma$-Proteobacteria and is regulated by the antiactivator NifL, while the second class is observed in $\alpha$-Proteobacteria, where NifL is absent. Nitrogen regulation by both mechanisms involves a PII-like protein and interaction with either NifL or NifA (2). In contrast, oxygen control differs between these two mechanisms. In $\gamma$-Proteobacteria, NifL senses oxygen levels through a flavin moiety (3), whereas in NifL-independent regulation, oxygen control is hypothesized to involve a putative Fe-S cluster associated with a cysteine tetrad located at the end of the central domain and ID-linker (4).

Herbaspirillum seropedicae is a nitrogen-fixing $\beta$-proteobacterium associated with important agricultural Gramineae, such as rice, wheat, sorghum, and sugarcane (5). Transcriptional control of nitrogen fixation in $H$. seropedicae relies on a NifL-independent NifA system that is controlled by both nitrogen and oxygen levels (6).

Correspondence: L.S. Chubatsu: <chubatsu@ufpr.br>.

Received November 18, 2014. Accepted March 26, 2015. First published online July 10, 2015. 
Recently the regulation of nitrogen fixation in this organism has been reviewed (7).

The $H$. seropedicae NifA N-terminal GAF domain comprises the first 184 amino acids (Figure 1), and although it is involved in negative regulation by ammonium, it is not strictly required for activation of nif gene transcription $(6,8)$. This N-terminal GAF domain interacts with GInK in response to the fixed nitrogen concentration (9). The N-terminal GAF domain is linked to the central domain by the 18 amino acids of the $\mathrm{Q}$-linker. The $H$. seropedicae NifA central domain comprises 236 amino acids and contains the catalytic site. It also interacts with the $\sigma^{54}$ RNA polymerase holoenzyme (4). The central domain is linked to the C-terminal domain by a 58 -amino acid region named the ID-linker. A conserved cysteine motif located at the end of the central domain and the ID-linker (positions 414, 426, 446, and 451) is suggested to be involved in the regulation of NifA by $\mathrm{O}_{2}$. Mutation of these cysteine residues produces inactive proteins (10). Finally, the last 43 amino acids of the NifA primary sequence form the $\mathrm{C}$-terminal domain, which is responsible for DNA binding (11).

In this work, site-directed mutagenesis was used to determine amino acid residues in $H$. seropedicae NifA that are important for its control.

\section{Material and Methods}

\section{Reagents}

All chemicals were analytical or molecular biology grade and were purchased from Merck (Germany), Sigma (USA), J.T. Baker (Netherlands), or Invitrogen (USA). Restriction enzymes were obtained from Fermentas (Lithuania) or Invitrogen. Oligonucleotides were synthesized by IDT (USA).

\section{Bacterial strains and growth conditions}

E. coli strains TOP10 (Invitrogen) and S17.1 (12) were used for cloning and conjugation procedures. E. coli were

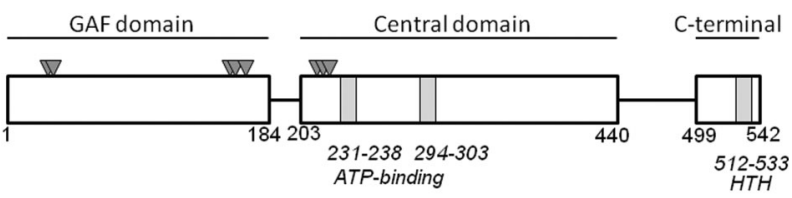

Figure 1. Scheme of Herbaspirillum seropedicae NifA domains. Numbers indicate the amino acid position on the primary structure. The N-terminal GAF domain, central domain, and C-terminal domain are indicated as open rectangles. The ATP-binding motifs, located in the central domain, and the helix-turn-helix $(\mathrm{HTH})$ motif in the C-terminal domain are indicated as gray rectangles, and were predicted using the ScanProsite tool (http://prosite.expasy.org/scanprosite) (29) and Gym2.0 (30), respectively. Point-mutations (K22V, G25E, T160E, M161V, L172R, A215D, Q216I, and S220I) are indicated by gray triangles in the N-terminal GAF and central domains of NifA. cultured at $37^{\circ} \mathrm{C}$ in Luria-Bertani broth, terrific broth, super optimal broth (SOB), or SOB with catabolite repression (SOC) broth media (13). $H$. seropedicae strains (Table 1) were grown in NFbHP medium at $30^{\circ} \mathrm{C}(14)$ with $37 \mathrm{mM}$ malate and $20 \mathrm{mM} \mathrm{NH}_{4} \mathrm{Cl}$ or $0.5 \mathrm{mM}$ glutamate.

\section{Site-directed mutagenesis}

Point mutations were introduced into the $H$. seropedicae nifA gene using mutagenic primers (Supplementary Table S1) as described previously (15). The mutated genes were then cloned into pET-29a, using Ndel and BamHI restriction sites, or into pLAFR3.18 (Xbal/HindIII restriction sites) for activity analyses in $E$. coli or $H$. seropedicae, respectively. These plasmids are listed in Table 1.

\section{Construction of $\boldsymbol{H}$. seropedicae mutants}

The nifA gene, cloned into pRAM1T7 as an Ndel/BamHI fragment, was digested with EcoRI to remove $750 \mathrm{bp}$ from the central region of nifA. Following re-ligation, the resulting plasmid (pBA3) was digested with $\mathrm{BamHI}$, and a sacB::Km cassette, obtained as a BamHI fragment from $\mathrm{pMH} 1701$, was introduced into pBA3, producing pBA4. This plasmid was then introduced into $H$. seropedicae SmR1 (wild type) and LNglnKdel, a glnK mutant (16), by electroporation (10 kV/cm, 4 k $\Omega, 330 \mu \mathrm{F}$, using a Gibco Cell-Porator, USA). Transformed cells were first selected by growth in NFbHP medium with $1 \mathrm{mg} / \mathrm{mL}$ kanamycin, and then by survival in NFbHP medium with $15 \%(\mathrm{w} / \mathrm{v})$ sucrose to obtain mutants with a second recombination. The nifA mutation was confirmed by DNA amplification using $1 \mathrm{U}$ Taq DNA Polymerase (Fermentas) in Taq buffer with $\left(\mathrm{NH}_{4}\right)_{2} \mathrm{SO}_{4}$, $3 \mathrm{mM} \mathrm{MgCl}_{2}, 0.8 \mathrm{mM}$ dNTP and $0.4 \mu \mathrm{M}$ of primers HSNifA1 and HSNifA2a (Supplementary Table S1) and the following parameters: one step for $5 \mathrm{~min}$ at $95^{\circ} \mathrm{C}$ and 30 cycles of $30 \mathrm{~s}$ at $95^{\circ} \mathrm{C}, 30 \mathrm{~s}$ at $45^{\circ} \mathrm{C}$ and $2 \mathrm{~min}$ at $72^{\circ} \mathrm{C}$. These strains were named NifAdel and NifAdel/GlnKdel, respectively.

$H$. seropedicae mutants carrying a chromosomal nifH::lacZ fusion were generated by introducing the pTZnifH::lacZ plasmid by electroporation, followed by selection for kanamycin resistance. The pTZnifH::lacZ plasmid was constructed by cloning a lacZ::Km cassette at the BamHI site located downstream from the 5.3-kb fragment containing part of $H$. seropedicae nifH and its promoter region in the pLAU1 plasmid. The lacZ::Km cassette was obtained as a BamHI fragment from the pKOK6.1 plasmid.

\section{Protein analyses}

$\beta$-galactosidase activity was determined as described previously (17). E. coli strain JM109(DE3), carrying plasmids pRT22 (Klebsiella pneumoniae nifH::lacZ) and pET-29a with different nifA mutations, was analyzed as described previously (9). The $\beta$-galactosidase activity in $H$. seropedicae was determined as described previously (16). Nitrogenase activity was determined using cells 
Table 1. Bacterial strains and plasmids.

\begin{tabular}{|c|c|c|}
\hline Strain/Plasmid & Characteristics & Reference \\
\hline \multicolumn{3}{|l|}{ Escherichia coli } \\
\hline JM109(DE3) & $\begin{array}{l}\text { recA1 supE44 endA1 hsdR17 gyrA96 relA1 thi } \Delta \text { (lac-proAB) } F^{\prime}[\text { traD36 } \\
\text { proAB }{ }^{+} \text {lac/ }{ }^{q} \text { lacZLM15] } \lambda \text { DE3 }\end{array}$ & Promega \\
\hline TOP10 & $\begin{array}{l}\mathrm{F}^{\prime} \text { mcrA } \Delta(m v r-\text { hrd } R M S-m c r B C) \phi 80 \text { lacZ } \Delta \mathrm{ML} 5 \Delta \text { lacX74 deoR recA1 } \\
\quad \operatorname{araD} 139 \Delta(a r a-l e u) 7697 \text { galU galK rpsL }\left(\mathrm{Sm}^{\mathrm{R}}\right) \text { endA1 nupG }\end{array}$ & Invitrogen \\
\hline $\mathrm{S} 17.1$ & $\mathrm{Sm}^{\mathrm{R}}$, tra + pro thi recA hsdR (RP4-2 kan::Tn7 tet::Mu) & 12 \\
\hline \multicolumn{3}{|c|}{ Herbaspirillum seropedicae } \\
\hline SmR1 & $\mathrm{Sm}^{\mathrm{R}}, \mathrm{Nif}^{+}$ & 32 \\
\hline LNglnKdel & $\mathrm{Sm}^{\mathrm{R}}, \mathrm{SmR} 1$ strain carrying an in frame deletion of $192 \mathrm{bp}$ of the glnK gene & 16 \\
\hline NifAdel & $\mathrm{Sm}^{\mathrm{R}}, \mathrm{SmR} 1$ strain carrying an in frame deletion of $750 \mathrm{bp}$ of the nifA gene & This work \\
\hline NifAdel/GInKdel & $\begin{array}{l}\mathrm{Sm}^{\mathrm{R}} \text {, LNglnKdel strain carrying an in frame deletion of } 750 \text { bp of the nifA } \\
\text { gene }\end{array}$ & This work \\
\hline \multicolumn{3}{|c|}{ J } \\
\hline pBA3 & $\begin{array}{l}\mathrm{Amp}^{\mathrm{R}}, H \text {. seropedicae nifA carrying a } 750 \mathrm{bp} \text { deletion at its central portion } \\
\text { from pRAM1T7 plasmid }\end{array}$ & This work \\
\hline pBA4 & $A m p^{R}, p B A 3$ plasmid with a sacB::Km cassette & This work \\
\hline pCR 2.1 & $A m p^{R}, \mathrm{Km}^{\mathrm{R}}$, cloning vector & Life Technologies \\
\hline pET29a & $\mathrm{Km}^{\mathrm{R}}, T 7$ promoter expression vector; His-tag fusion & Novagen \\
\hline pET-A215D & $\begin{array}{l}\mathrm{Km}^{\mathrm{R}} \text {, contains a } H \text {. seropedicae nifA gene with the } \mathrm{A} 215 \mathrm{D} \text { mutation cloned } \\
\text { into } \mathrm{pET}-29 \mathrm{a}\end{array}$ & This work \\
\hline pET-G25E & $\begin{array}{l}\mathrm{Km}^{\mathrm{R}} \text {, contains a } H \text {. seropedicae nifA gene with the G25E mutation cloned } \\
\text { into } \mathrm{pET}-29 \mathrm{a}\end{array}$ & This work \\
\hline pET-K22V & $\begin{array}{l}\mathrm{Km}^{\mathrm{R}} \text {, contains a } H \text {. seropedicae nifA gene with the } \mathrm{K} 22 \mathrm{~V} \text { mutation cloned } \\
\text { into } \mathrm{pET}-29 \mathrm{a}\end{array}$ & This work \\
\hline pET-L172R & $\begin{array}{l}\mathrm{Km}^{\mathrm{R}} \text {, contains a } H \text {. seropedicae nifA gene with the L172R mutation cloned } \\
\text { into } \mathrm{pET}-29 \mathrm{a}\end{array}$ & This work \\
\hline pET-M161V & $\begin{array}{l}\mathrm{Km}^{\mathrm{R}} \text {, contains a } H \text {. seropedicae nifA gene with the M161V mutation cloned } \\
\text { into pET-29a }\end{array}$ & This work \\
\hline pET-Q216I & $\begin{array}{l}\mathrm{Km}^{\mathrm{R}} \text {, contains a } H \text {. seropedicae nifA gene with the Q216I mutation cloned } \\
\text { into pET-29a }\end{array}$ & This work \\
\hline pET-S220I & $\begin{array}{l}\mathrm{Km}^{\mathrm{R}} \text {, contains a } H \text {. seropedicae nifA gene with the } \mathrm{S} 220 \mathrm{I} \text { mutation cloned } \\
\text { into } \mathrm{pET}-29 \mathrm{a}\end{array}$ & This work \\
\hline pET-T160E & $\begin{array}{l}\mathrm{Km}^{\mathrm{R}} \text {, contains a } H \text {. seropedicae nifA gene with the T160E mutation cloned } \\
\text { into pET-29a }\end{array}$ & This work \\
\hline $\mathrm{pET}-\Delta \mathrm{N}-\mathrm{A} 215 \mathrm{D}$ & $\begin{array}{l}\mathrm{Km}^{\mathrm{R}} \text {, expresses an } \mathrm{N} \text {-truncated NifA protein of } H \text {. seropedicae without its } \\
\text { first } 203 \text { amino acids and carrying the mutation A215D; pET-29a based } \\
\text { plasmid }\end{array}$ & This work \\
\hline $\mathrm{pET}-\Delta \mathrm{N}-\mathrm{Q} 216 \mathrm{I}$ & $\begin{array}{l}\mathrm{Km}^{\mathrm{R}} \text {, expresses an N-truncated NifA protein of } H \text {. seropedicae without its } \\
\text { first } 203 \text { amino acids and carrying the mutation Q216I; pET-29a based } \\
\text { plasmid }\end{array}$ & This work \\
\hline $\mathrm{pET}-\Delta \mathrm{N}-\mathrm{S} 22 \mathrm{Ol}$ & $\begin{array}{l}\mathrm{Km}^{\mathrm{R}} \text {, expresses an N-truncated NifA protein of } H \text {. seropedicae without its } \\
\text { first } 203 \text { amino acids and carrying the mutation S220I; pET-29a based } \\
\text { plasmid }\end{array}$ & This work \\
\hline pKOK 6.1 & $A m p^{R}, \mathrm{Cm}^{\mathrm{R}}, \mathrm{Km}^{\mathrm{R}}$, contains a promotor-less lacZ-Km${ }^{R}$ cassette & 33 \\
\hline pLAFR3.18 & CmR, TcR, Mob +, IncP cosmid with the pTZ18R cloning nest & 6,34 \\
\hline pLAFR-A215D & $\begin{array}{l}\mathrm{TC}^{\mathrm{R}} \text {, contains a } H \text {. seropedicae nifA gene with the A215D mutation cloned } \\
\text { into pLAFR3.18 }\end{array}$ & This work \\
\hline pLAFR-G25E & $\begin{array}{l}\mathrm{Tc}^{\mathrm{R}} \text {, contains a } H \text {. seropedicae nifA gene with the G25E mutation cloned } \\
\text { into pLAFR3.18 }\end{array}$ & This work \\
\hline pLAFR-K22V & $\begin{array}{l}\mathrm{Tc}^{\mathrm{R}} \text {, contains a } \mathrm{H} \text {. seropedicae nifA gene with the } \mathrm{K} 22 \mathrm{~V} \text { mutation cloned into } \\
\text { pLAFR3.18 }\end{array}$ & This work \\
\hline
\end{tabular}


Table 1. Continued.

\begin{tabular}{|c|c|c|}
\hline Strain/Plasmid & Characteristics & Reference \\
\hline pLAFR-L172R & $\begin{array}{l}\mathrm{Tc}^{\mathrm{R}} \text {, contains a } H \text {. seropedicae nifA gene with the L172R mutation cloned } \\
\text { into pLAFR3.18 }\end{array}$ & This work \\
\hline pLAFR-M161V & $\begin{array}{l}\mathrm{Tc}^{\mathrm{R}} \text {, contains a } H \text {. seropedicae nifA gene with the M161V mutation cloned } \\
\text { into pLAFR3.18 }\end{array}$ & This work \\
\hline pLAFR-Q216I & $\begin{array}{l}\mathrm{Tc}^{\mathrm{R}} \text {, contains a } H \text {. seropedicae nifA gene with the Q216I mutation cloned } \\
\text { into pLAFR3.18 }\end{array}$ & This work \\
\hline pLAFR-S220I & $\begin{array}{l}\mathrm{Tc}^{\mathrm{R}} \text {, contains a } H \text {. seropedicae nifA gene with the } \mathrm{S} 220 \mathrm{I} \text { mutation cloned } \\
\text { into pLAFR3.18 }\end{array}$ & This work \\
\hline pLAFR-T160E & $\begin{array}{l}\mathrm{Tc}^{\mathrm{R}} \text {, contains a } H \text {. seropedicae nifA gene with the T160E mutation cloned } \\
\text { into pLAFR3.18 }\end{array}$ & This work \\
\hline pLAU1 & $\begin{array}{l}\mathrm{Amp}^{\mathrm{R}} ; \mathrm{pTZ18R} \text {-based plasmid contains a } 5.3 \mathrm{~kb} \text { fragment of } H . \\
\text { seropedicae including part of the nifH gene and its promoter region }\end{array}$ & 35 \\
\hline pMH1701 & $\mathrm{Km}^{\mathrm{R}}$, contains a $\operatorname{sacB}-\mathrm{Km}^{R}$ cassette & 36 \\
\hline ppnifAN185 & $\begin{array}{l}\mathrm{Tc}^{\mathrm{R}} \text {, expresses an } \mathrm{N} \text {-truncated NifA protein of } H \text {. seropedicae without its first } \\
185 \text { amino acids upon its own promotor; pLAFR3.18 based plasmid }\end{array}$ & $\begin{array}{l}\text { Stefanello A.A. } \\
\text { (unpublished) }\end{array}$ \\
\hline pRAM1 & $\mathrm{Km}^{\mathrm{R}}, H$. seropedicae nifA into $\mathrm{pET} 29 \mathrm{a}$ vector & 8 \\
\hline pRAM1T7 & $\begin{array}{l}\text { Amp }^{\mathrm{R}}, H \text {. seropedicae nifA removed as a Ndel/BamHI fragment from } \\
\text { pRAM1 and cloned into pT7-7 vector }\end{array}$ & 37 \\
\hline pRAM2 & $\begin{array}{l}\mathrm{Km}^{\mathrm{R}} \text {, expresses an } \mathrm{N} \text {-truncated NifA protein of } H \text {. seropedicae without its } \\
\text { first } 203 \text { amino acids; pET29a based plasmid }\end{array}$ & 8 \\
\hline pRAMM1 & $\mathrm{Tc}^{\mathrm{R}}, H$. seropedicae nifA into pLAFR3.18 vector & 16 \\
\hline pRT22 & $\mathrm{Cm}^{\mathrm{R}}, \mathrm{K}$. pneumoniae nifH::/acZ & 38 \\
\hline pT7-7 & $A m p^{R}, T 7$ promoter expression vector & Biolabs \\
\hline pTZ18R & $A m p^{R}$, cloning vector carrying lac promoter & 39 \\
\hline pTZnifH::lacZ & $\begin{array}{l}\mathrm{Amp}^{\mathrm{R}}, \mathrm{Km}^{\mathrm{R}} \text {, contains a } H \text {. seropedicae nifH:lacZ fusion; pLAU1 based } \\
\text { plasmid }\end{array}$ & This work \\
\hline
\end{tabular}

$A m p^{R}, \mathrm{Cm}^{R}, \mathrm{Km}^{\mathrm{R}}, \mathrm{Tc}^{\mathrm{R}}$ : resistance to ampicillin, chloramphenicol, kanamycin or tetracycline, respectively.

grown in semi-solid NFbHP medium containing glutamate $(0.5 \mathrm{mM})$. Protein concentration was determined using the Bradford method (18) with bovine serum albumin as a standard.

\section{Results}

In this work, we generated eight constructs that introduced NifA point mutations (K22V, G25E, T160E, M161V, L172R, A215D, Q216I, and S220I) and analyzed their effects on transcriptional activation activity. Four mutations were based on described NifA mutations from Rhodospirillum rubrum (19) and Sinorhizobium meliloti (20), while the other four amino acids were chosen from among conserved residues (Supplementary Table S2). Residues were selected for mutagenesis by aligning NifA proteins from K. pneumoniae, Azoarcus sp., and Azotobacter vinelandii, which are regulated by NifL, and from $H$. seropedicae, $R$. rubrum, S. meliloti, Rhodobacter capsulatus, Bradyrhizobium japonicum, and Azospirillum brasilense, which are regulated in a NifL-independent manner (Supplementary Table S2). The mutations were located in the N-terminal GAF domain (K22V, G25E,
T160E, M161V, and $\mathrm{L} 172 \mathrm{R}$ ) and the central domain (A215D, Q216I, and S220I) of $H$. seropedicae NifA (Figure 1). The secondary structure of each mutant protein was predicted using the Psipred tool (21), which indicated no major differences in secondary structure between the mutants and wild-type NifA (data not shown).

The ability of the $H$. seropedicae NifA mutants to activate nif promoters was determined in E. coli JM109 (DE3) carrying plasmid pRT22 (K. pneumoniae nifH::/acZ fusion) (Figure 2). Full-length NifA, expressed from plasmid pRAM1, showed no $\beta$-galactosidase activity, consistent with previous descriptions, mainly because of lower expression of endogenous $E$. coli PII, which is necessary to relieve the negative control of the $\mathrm{N}$-terminal GAF domain on the catalytic domain of NifA (7). In contrast, the $\mathrm{N}$-terminal truncated NifA protein $(\Delta \mathrm{N}-\mathrm{NifA})$ expressed from pRAM2 was fully functional in $E$. coli regardless of the ammonium concentration (22). These results confirmed the regulatory role of the $\mathrm{N}$-terminal GAF domain on $H$. seropedicae NifA that has been described previously: in the presence of ammonium or the absence of PII, the N-terminal GAF inhibits NifA transcriptional activity $(6,23)$. The constructed NifA point mutants 


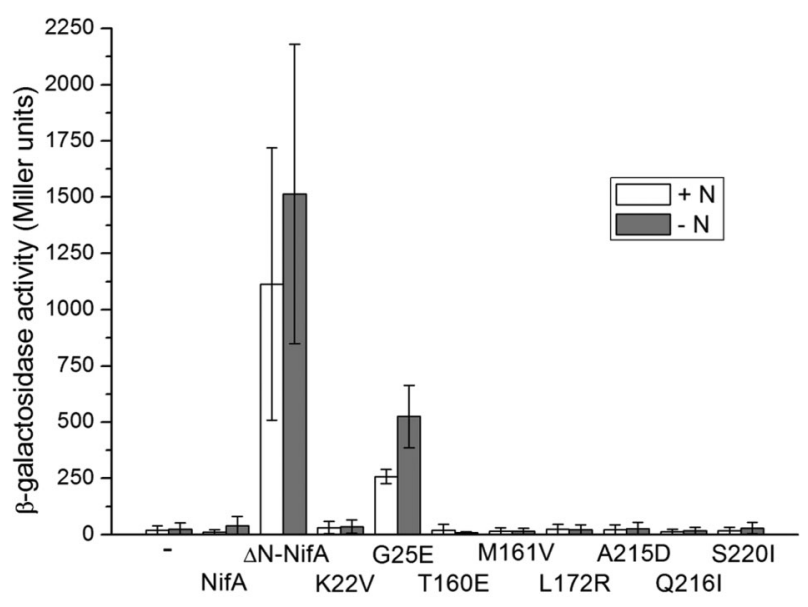

Figure 2. Transcriptional activity of NifA variant proteins in Escherichia coli JM109 (DE3) carrying pRT22 (nifH::lacZ). $(-)$ indicates cells carrying pET-29a. Full-length NifA was expressed from pRAM1. $\triangle \mathrm{N}$-NifA indicates an $\mathrm{N}$-truncated form of NifA expressed from pRAM2. Full-length NifA mutants, as indicated, were expressed from pET-29a-based plasmids. $\beta$-galactosidase expression experiments were performed in NFDM medium (31) with $20 \mathrm{mM}$ of ammonium chloride $(+\mathrm{N})$ or $0.2 \%$ casamino acids $(-\mathrm{N})$, in the absence of $\mathrm{O}_{2}$. Data are reported as the mean $\pm S D$ of 3 independent assays. $\beta$-galactosidase activity is reported as Miller units.

were analyzed under the same conditions and showed no activity, except for NifA G25E, which partially activated nifH transcription in E. coli. G25E also appeared to retain some nitrogen control, as activation of transcription was higher under low ammonium concentrations. This result indicated that the G25E substitution affected the need for PII for NifA activity in $H$. seropedicae.

Considering that A215D, Q216I, and S220I are located in the central domain of NifA, and that the full-length protein is inactive in E. coli (6) (Figure 2), these three mutations were also tested using an $\mathrm{N}$-truncated form (GAF truncated protein) (Figure 3). The removal of the first 203 amino acids of NifA yields an active protein in $E$. coli (8), as shown using protein expressed from plasmid pRAM2. The $\mathrm{N}$-truncated protein $(\Delta \mathrm{N}-\mathrm{NifA})$ was active regardless of the nitrogen level, but only under low $\mathrm{O}_{2}$, reinforcing its sensitivity toward $\mathrm{O}_{2}$. The $\mathrm{N}$-truncated $\Delta \mathrm{N}$ Q216I and $\Delta \mathrm{N}$-S220I mutants showed lower $\beta$-galactosidase activity than that expressed by pRAM2, indicating that these mutations negatively affect transcriptional activity, while retaining $\mathrm{O}_{2}$ responsiveness. In contrast, $\Delta \mathrm{N}-\mathrm{A} 215 \mathrm{D}$ was inactive under all tested conditions, suggesting that a negatively-charged amino acid at position 215 affects the catalytic activity of the protein. These proteins were expressed under all conditions tested, as determined by gel electrophoresis (data not shown). The three disrupted amino acids are close to the ATP-binding site, which is located at positions 231-238.
In contrast to $H$. seropedicae, a NifA strain with a mutation in this region (M217I) in S. meliloti was oxygen tolerant (20).

The point mutations were also analyzed in an $H$. seropedicae background. Assuming that a functional NifA variant leads to nif gene transcription, nitrogenase activity can be determined. However, for these assays it was necessary to construct two $H$. seropedicae mutant strains: a nifA mutant strain and a double mutant nifA/ glnK, both of which were obtained by partial gene deletion. These strains were named NifAdel and NifAdel/GInKdel, respectively. The nifA/gInK double mutant allowed detection of a NifA mutant that does not require GInK for activity, as this PII protein is responsible for relieving the nitrogen-regulated negative control of NifA (16). These $H$. seropedicae mutant strains showed no nitrogenase activity (acetylene reduction method; Table 2) (24,25). However, the nitrogenase activity was restored in the pRAMM1-carrying NifAdel strain, which expresses the fulllength NifA, and in the NifAdel/GInKdel strain carrying ppnifAN185, which expressed an N-truncated form of NifA (Table 2).

To analyze the effect of NifA mutations on nitrogenase activity, each construct was cloned into the pLAFR3.18 vector, which is stable in $H$. seropedicae, and transformed into both the NifAdel and NifAdel/GInKdel strains. Assays performed with NifAdel showed that the G25E mutant was fully active, Q216I was partially active, and the other mutants showed no significant nitrogenase activity (Table 2). However, NifA levels similar to those of the wild type were expressed from pRAMM1, while the Q216I mutant did not show any nitrogenase activity in the absence of GInK (assay in NifAdel/GInKdel strain). In contrast, the G25E mutant demonstrated nitrogenase activity, which implied that G25E was active and does not require GInK for activity.

The G25E mutation was also tested in the NifAdel and NifAdel/GInKdel strains carrying a nifH::lacZ chromosomal fusion, which allowed assessment of transcriptional NifA activity in the presence of high ammonium concentrations (Figure 4). The wild-type $H$. seropedicae strain (SmR1) carrying the nifH::lacZ fusion only showed $\beta$-galactosidase activity at low ammonium concentrations. Conversely, the G25E mutant showed nifH::/acZ transcription in both the NifAdel and NifAdel/GInKdel strains, regardless of ammonium concentration. However, comparison of $\beta$-galactosidase activity at both low and high ammonium concentrations indicated that the G25E mutant protein was partially regulated by ammonium, as transcriptional activity was higher at low ammonium concentrations. This result suggested that the G25E mutant did not depend on GInK for activity, but could still detect ammonium concentration.

\section{Discussion}

$H$. seropedicae NifA is regulated by both ammonium and oxygen (6). The effect of $\mathrm{O}_{2}$ on the NifA protein is 


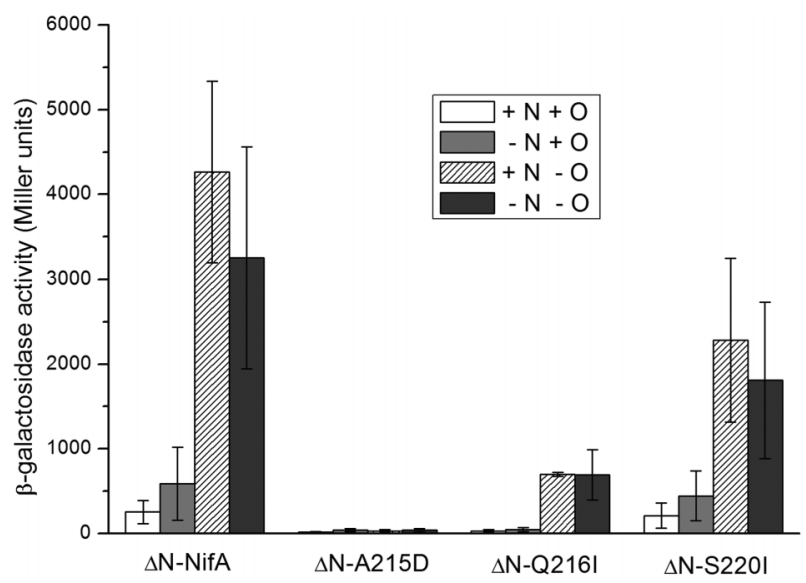

Figure 3. Transcriptional activity of $\Delta \mathrm{N}-\mathrm{NifA}$ mutant proteins in Escherichia coli JM109 (DE3) carrying pRT22 (nifH::lacZ). $\triangle \mathrm{N}$-NifA indicates NifA lacking 203 amino acid residues at the $\mathrm{N}$-terminal GAF domain. $\Delta \mathrm{N}-215 \mathrm{D}, \Delta \mathrm{N}-\mathrm{Q} 216 \mathrm{I}$, and $\Delta \mathrm{N}-\mathrm{S} 220 \mathrm{I}$ indicate the $\mathrm{N}$-truncated forms of NifA mutants. $\beta$-galactosidase expression experiments were performed in NFDM medium supplemented with $20 \mathrm{mM}$ ammonium chloride $(+\mathrm{N})$ or $0.2 \%$ casamino acids $(-\mathrm{N})$ in the presence $(+\mathrm{O})$ or absence $(-\mathrm{O})$ of $\mathrm{O}_{2}$. Data are reported as the mean $\pm \mathrm{SD}$ of 3 independent assays. $\beta$-galactosidase activity is reported as Miller units.

related to a putative Fe-S cluster involving four cysteine residues located at the end of the central domain and the ID-linker. These conserved cysteine residues are found in all NifA proteins that are directly sensitive to oxygen, but absent in NifA proteins that depend on NifL for oxygen control (4). In $H$. seropedicae, mutation of the conserved cysteine residues rendered inactive proteins (10). Conversely, Krey et al. (20) obtained a $S$. meliloti NifA mutant (M217I) that was active even under high $\mathrm{O}_{2}$ levels. Using sequence alignment, we determined the corresponding amino acid residue in $H$. seropedicae to be serine 220 . The NifA S220I mutation resulted in lower activity in $H$. seropedicae (Table 2) and partial activity in E. coli (Figure 3), but retained sensitivity toward $\mathrm{O}_{2}$, indicating a difference in behavior compared with S. meliloti NifA M217I.

Two further amino acid residues close to $S 220$ in $H$. seropedicae NifA were also mutated and analyzed. The A215D mutation was benign in both $H$. seropedicae and $E$. coli, even if an $\mathrm{N}$-truncated form was used. However, the N-truncated protein form carrying the Q216I mutation showed transcriptional activity dependent on $\mathrm{O}_{2}$. This mutant Q216I $H$. seropedicae strain also produced an active nitrogenase complex dependent on the GlnK protein, similar to the wild type. These results indicate that Q216I and S220I retained regulatory activities similar to the wild type, although with lower activity. Conversely, because no transcription from strains carrying the A215D mutation was observed under any of the conditions tested, the alanine residue at position 215 is likely to be essential for activity. Alternatively, a negative charge at position 215 may be more deleterious for $H$. seropedicae NifA compared with the previous substitutions.

Mutations M161V and L172R in $H$. seropedicae NifA correspond to mutations M173V and L184R described previously in $R$. rubrum (19). Analysis carried out using a yeast two-hybrid system showed that $R r M 173 \mathrm{~V}$ produced a protein with stronger $\mathrm{GlnB}$ interaction, whereas the RrL184R mutant did not require GlnB for activity. In R. rubrum, GInB is the PII protein responsible for controlling NifA activity (26). The $H$. seropedicae NifA M161V mutant was inactive in all conditions tested, while the L172R mutant showed very low nitrogenase activity, indicating that these amino acids are important for the overall NifA activity.

$H$. seropedicae differs from $R$. rubrum in that nitrogen regulation depends on GInK (16). Among the eight $H$. seropedicae NifA mutations investigated in this work, the G25E mutation rendered an active NifA protein that did not require GInK. Mutation G25E in $H$. seropedicae corresponds to G36E in $R$. rubrum, which also produced a partial active NifA independent of GInB (19). The G25E mutation may affect the negative regulatory interaction between the $\mathrm{N}$-terminal GAF domain and the catalytic central domain under high ammonium concentrations, resulting in a constitutively active protein. Furthermore, the glutamate residue at position 25 could lead to a

Table 2. Effect of NifA mutations on $H$. seropedicae nitrogenase activity.

\begin{tabular}{lcc}
\hline \multirow{2}{*}{ Construct } & \multicolumn{2}{c}{ Herbaspirillum seropedicae strains } \\
\cline { 2 - 3 } & NifAdel & NifAdel/GInKdel \\
\hline- & $0.02 \pm 0.03$ & 0 \\
pRAMM1 & $3.3 \pm 1.5$ & $0.05 \pm 0.09$ \\
ppnifAN185 & nd & $10 \pm 7$ \\
K22V & 0 & 0 \\
G25E & $19 \pm 6$ & $13 \pm 2$ \\
T160E & 0 & 0 \\
M161V & 0 & 0 \\
L172R & $0.15 \pm 0.04$ & 0 \\
A215D & 0 & 0 \\
Q216I & $2.7 \pm 0.6$ & 0 \\
S220I & $0.58 \pm 0.07$ & 0
\end{tabular}

Nitrogenase activity was determined as described using strains NifAdel and NifAdel/GInKdel grown in semi-solid medium. Strains carrying plasmids expressing wild-type NifA (pRAMM1), an $\mathrm{N}$-truncated NifA (ppnifAN185), or the indicated NifA mutants expressed from pLAFR3.18-based plasmids were assayed. Data are reported as the mean $\pm S D$ of at least 3 independent experiments. Nitrogenase activity is reported as $\mathrm{nmol}$ ethylene $\cdot \mathrm{mg}$ protein $^{-1} \cdot \min ^{-1}$. The nitrogenase activity in the $H$. seropedicae SmR1 strain (wild type) was $13 \pm 1 \mathrm{nmol}$ ethylene $\cdot \mathrm{mg}$ protein ${ }^{-1} \cdot \min ^{-1}$. nd: not determined. 


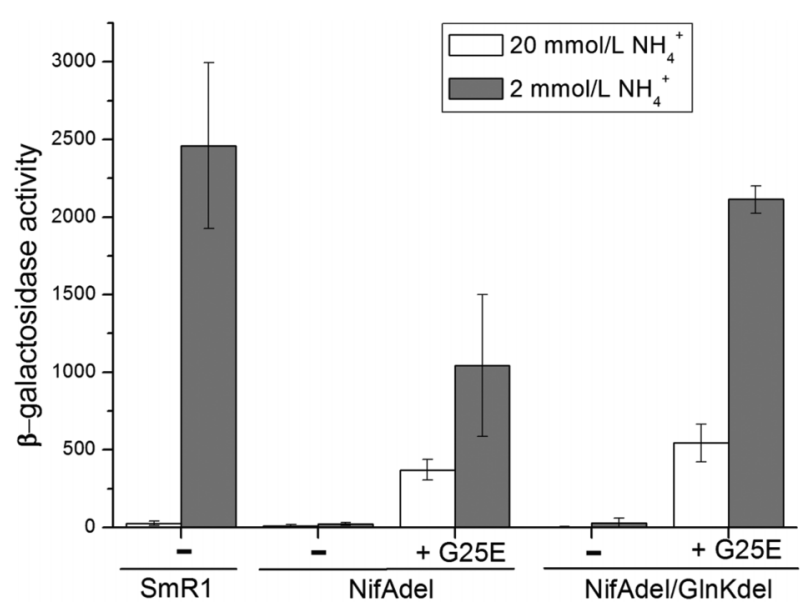

Figure 4. Transcriptional activity of indicated Herbaspirillum seropedicae strains carrying a chromosomal nifH:lacZ fusion. + G25E indicates cells carrying a pLAFR3.18-based plasmid expressing the G25E NifA mutant; (-) indicates absence of plasmid. Cells were grown in NFbHP medium supplemented with $10 \mathrm{mM} \mathrm{NH}_{4} \mathrm{Cl}$ under aerobic conditions at $30^{\circ} \mathrm{C}$. Cells were then centrifuged (1700 $\mathrm{g}$ for $2 \mathrm{~min}$ ), resuspended in NFbHP (nitrogenfree) medium, and de-repressed for $7 \mathrm{~h}$ under $1.5 \%$ oxygen. $\beta$-galactosidase was determined as described. Data are reported as the mean $\pm S D$ of at least 3 independent experiments. $\beta$-galactosidase activity is reported as Miller units.

conformational change comparable with that produced when GInK interacts with the N-terminal GAF domain.

The G25E mutant was also analyzed using a nifH:lacZ chromosomal fusion in $H$. seropedicae (Figure 4). This allowed us to determine the NifA transcriptional activity

\section{References}

1. Dixon R, Kahn D. Genetic regulation of biological nitrogen fixation. Nat Rev Microbiol 2004; 2: 621-631, doi: 10.1038/ nrmicro954.

2. Huergo LF, Chandra G, Merrick M. P(II) signal transduction proteins: nitrogen regulation and beyond. FEMS Microbiol Rev 2013; 37: 251-283.

3. Martinez-Argudo I, Little R, Shearer N, Johnson P, Dixon R. The NifL-NifA System: a multidomain transcriptional regulatory complex that integrates environmental signals. J Bacteriol 2004; 186: 601-610, doi: 10.1128/JB.186.3.601-610.2004.

4. Fischer HM. Genetic regulation of nitrogen fixation in rhizobia. Microbiol Rev 1994; 58: 352-386.

5. Baldani JI, Baldani VLD, Seldin L, Dobereiner J. Characterization of Herbaspirillum seropedicae gen. nov., sp. nov., a root-associated nitrogen-fixing bacterium. Int J Syst Bacteriol 1986; 36: 86-93, doi: 10.1099/00207713-36-1-86.

6. Souza EM, Pedrosa FO, Drummond M, Rigo LU, Yates MG. Control of Herbaspirillum seropedicae NifA activity by ammonium ions and oxygen. J Bacteriol 1999; 181: 681-684.

7. Chubatsu LS, Monteiro RA, Souza EM, Oliveira MAS, Yates MG, Wassem R, et al. Nitrogen fixation control in even in the presence of high ammonium concentrations, a condition where nitrogenase activity is not observed (16). The assay showed that the G25E mutant is active in the absence of GInK, as observed by nitrogenase activity, but also showed partial regulation by fixed nitrogen, with higher transcriptional activity under low ammonium concentrations than in the presence of high ammonium concentrations (Figure 4). The partial regulation by fixed nitrogen was also observed in assays performed in E. coli (Figure 2).

The observed ammonium regulation could be related to the GAF domain, which has been shown to bind small molecules such as cyclic nucleotides and 2-oxoglutarate (27). In A. vinelandii, formation of the NifL-NifA complex is prevented by the binding of 2-oxoglutarate to the NifA GAF domain (28). Although it has not been confirmed that the N-terminal GAF domain of $H$. seropedicae NifA binds small molecules, the possibility that a small molecule such as 2-oxoglutarate may interact with the protein, signaling a cellular deficit of fixed nitrogen, cannot be ruled out.

\section{Supplementary material}

Click here to view [pdf].

\section{Acknowledgments}

We are grateful to Roseli Prado, Julieta Pie, Marilza Lamour, and Valter A. Baura for their technical assistance. This work was supported by INCT-Fixação Biológica de Nitrogênio, CNPq, CAPES and PNPD/CAPES.

Herbaspirillum seropedicae. Plant Soil 2012; 356: 197-207, doi: 10.1007/s11104-011-0819-6.

8. Monteiro RA, Souza EM, Funayama S, Yates MG, Pedrosa FO, Chubatsu LS. Expression and functional analysis of an $\mathrm{N}$-truncated NifA protein of Herbaspirillum seropedicae. FEBS Lett 1999; 447: 283-286, doi: 10.1016/S0014-5793 (99)00314-2.

9. Oliveira MA, Aquino B, Bonatto AC, Huergo LF, Chubatsu LS, Pedrosa FO, et al. Interaction of GInK with the GAF domain of Herbaspirillum seropedicae NifA mediates $\mathrm{NH}(4)(+)$-regulation. Biochimie 2012; 94: 1041-1047, doi: 10.1016/j.biochi.2012.01.007.

10. Oliveira MA, Baura VA, Aquino B, Huergo LF, Kadowaki MA, Chubatsu LS, et al. Role of conserved cysteine residues in Herbaspirillum seropedicae NifA activity. Res Microbiol 2009; 160: 389-395, doi: 10.1016/j.resmic.2009.06.002.

11. Monteiro RA, Souza EM, Geoffrey YM, Steffens MB, Pedrosa FO, Chubatsu LS. Expression, purification, and functional analysis of the C-terminal domain of Herbaspirillum seropedicae NifA protein. Protein Expr Purif 2003; 27: 313-318, doi: 10.1016/S1046-5928(02)00635-6. 
12. Simon R, Priefer U, Puhler A. A broad host range mobilization system for in vivo genetic engineering: transposon mutagenesis in gram-negative bacteria. Nat Biotechnol 1983; 1: 784-791, doi: 10.1038/nbt1183-784.

13. Sambrook J, Fritsch EF, Maniatis T. Molecular cloning: A laboratory manual. 2nd edn. New York: Cold Spring Harbor Laboratory Press; 1989.

14. Klassen G, Pedrosa FO, Souza EM, Funayama S, Rigo LU. Effect of nitrogen compounds on nitrogenase activity in Herbaspirillum seropedicae SMR1. Can J Microbiol 1997; 43: 887-891.

15. Erlich HA. PCR Technology - Principles and applications for DNA amplification. New York: W.H. Freeman and Company; 1992.

16. Noindorf L, Bonatto AC, Monteiro RA, Souza EM, Rigo LU, Pedrosa FO, et al. Role of PIl proteins in nitrogen fixation control of Herbaspirillum seropedicae strain SmR1. BMC Microbiol 2011; 11: 8, doi: 10.1186/1471-2180-11-8.

17. Miller JH. Experiments in molecular genetics. Cold Spring Harbor: Cold Spring Harbor Laboratory; 1972.

18. Bradford MM. A rapid and sensitive method for the quantitation of microgram quantities of protein utilizing the principle of protein-dye binding. Anal Biochem 1976; 72: 248-254, doi: 10.1016/0003-2697(76)90527-3.

19. Zou X, Zhu Y, Pohlmann EL, Li J, Zhang Y, Roberts GP. Identification and functional characterization of NifA variants that are independent of GlnB activation in the photosynthetic bacterium Rhodospirillum rubrum. Microbiology 2008; 154: 2689-2699, doi: 10.1099/mic.0.2008/ 019406-0.

20. Krey R, Puhler A, Klipp W. A defined amino acid exchange close to the putative nucleotide binding site is responsible for an oxygen-tolerant variant of the Rhizobium meliloti NifA protein. Mol Gen Genet 1992; 234: 433-441, doi: 10.1007/ BF00538703.

21. Buchan DW, Minneci F, Nugent TC, Bryson K, Jones DT. Scalable web services for the PSIPRED Protein Analysis Workbench. Nucleic Acids Res 2013; 41: W349-W357, doi: $10.1093 /$ nar/gkt381.

22. Monteiro RA, Souza EM, Yates MG, Pedrosa FO, Chubatsu LS. In-trans regulation of the N-truncated-NIFA protein of Herbaspirillum seropedicae by the $\mathrm{N}$-terminal domain. FEMS Microbiol Lett 1999; 180: 157-161, doi: 10.1111/ fml.1999.180.issue-2.

23. Monteiro RA, de Souza EM, Wassem R, Yates MG, Pedrosa FO, Chubatsu LS. Inter-domain cross-talk controls the NifA protein activity of Herbaspirillum seropedicae. FEBS Lett 2001; 508: 1-4, doi: 10.1016/S0014-5793(01)03017-4.

24. Dilworth MJ. Acetylene reduction by nitrogen-fixing preparations from Clostridium pasteurianum. Biochim Biophys Acta 1966; 127: 285-294, doi: 10.1016/0304-4165(66)90383-7.

25. Schollhorn R, Burris $\mathrm{RH}$. Acetylene as a competitive inhibitor of N-2 fixation. Proc Natl Acad Sci U S A 1967; 58: 213-216, doi: 10.1073/pnas.58.1.213.

26. Zhang Y, Pohlmann EL, Ludden PW, Roberts GP. Functional characterization of three GlnB homologs in the photosynthetic bacterium Rhodospirillum rubrum: roles in sensing ammonium and energy status. J Bacteriol 2001; 183: 6159-6168, doi: 10.1128/JB.183.21.6159-6168.2001

27. Ho YS, Burden LM, Hurley JH. Structure of the GAF domain, a ubiquitous signaling motif and a new class of cyclic GMP receptor. EMBO J 2000; 19: 5288-5299.

28. Little $R$, Dixon R. The amino-terminal GAF domain of Azotobacter vinelandii NifA binds 2-oxoglutarate to resist inhibition by NifL under nitrogen-limiting conditions. J Biol Chem 2003; 278: 28711-28718, doi: 10.1074/jbc.M301992200.

29. de Castro E, Sigrist CJ, Gattiker A, Bulliard V, LangendijkGenevaux PS, Gasteiger E, et al. ScanProsite: detection of PROSITE signature matches and ProRule-associated functional and structural residues in proteins. Nucleic Acids Res 2006; 34: W362-W365, doi: 10.1093/nar/gkl124.

30. Narasimhan G, Bu C, Gao Y, Wang X, Xu N, Mathee K. Mining protein sequences for motifs. J Comput Biol 2002; 9: 707-720, doi: 10.1089/106652702761034145.

31. Cannon FC, Dixon RA, Postgate JR, Primrose SB. Chromosomal integration of Klebsiella nitrogen fixation genes in Escherichia coli. J Gen Microbiol 1974; 80: 227-239.

32. Pedrosa FO, Teixeira KRS, Machado IMP, Steffens MBR, Klassen G, Benelli EM, et al. Structural organization and regulation of the nif genes of Herbaspirillum seropedicae. Soil Biol Biochem 1997; 29: 843-846, doi: 10.1016/S00380717(96)00206-4.

33. Kokotek W, Lotz W. Construction of a lacZ-kanamycinresistance cassette, useful for site-directed mutagenesis and as a promoter probe. Gene 1989; 84: 467-471, doi: 10.1016/0378-1119(89)90522-2.

34. Staskawicz B, Dahlbeck D, Keen N, Napoli C. Molecular characterization of cloned avirulence genes from race 0 and race 1 of Pseudomonas syringae pv. glycinea. J Bacteriol 1987; 169: 5789-5794.

35. Roncato-Maccari LD, Ramos HJ, Pedrosa FO, Alquini Y, Chubatsu LS, Yates MG, et al. Endophytic Herbaspirillum seropedicae expresses nif genes in gramineous plants. FEMS Microbiol Ecol 2003; 45: 39-47, doi: 10.1016/S01686496(03)00108-9.

36. Hynes MF, Quandt J, O'Connell MP, Puhler A. Direct selection for curing and deletion of Rhizobium plasmids using transposons carrying the Bacillus subtilis sacB gene. Gene 1989; 78 : 111-120, doi: 10.1016/0378-1119(89)90319-3.

37. Batista MB, Wassem R, de Oliveira Pedrosa F, Souza EM, Dixon R, Monteiro RA. Enhanced oxygen consumption in Herbaspirillum seropedicae fnr mutants leads to increased NifA mediated transcription activation. BMC Microbiol 2015; 15: 95, doi: 10.1186/s12866-015-0432-6.

38. Tuli R, Merrick MJ. Over-production and characterization of the nifA gene product of Klebsiella pneumoniae - the transcriptional activator of nif gene expression. J Gen Microbiol 1988; 134: 425-432, doi: 10.1099/00221287-134-2-425.

39. Mead DA, Szczesna-Skorupa E, Kemper B. Single-stranded DNA 'blue' T7 promoter plasmids: a versatile tandem promoter system for cloning and protein engineering. Protein Eng 1986; 1: 67-74, doi: 10.1093/protein/1.1.67. 